\title{
ACE-inhibition increases hepatic and extrahepatic sensitivity to insulin in patients with Type 2 (non-insulin-dependent) diabetes mellitus and arterial hypertension
}

\author{
E.Torlone, A. M. Rambotti, G.Perriello, G. Botta, F. Santeusanio, P. Brunetti and G. B. Bolli \\ Istituto di Patologia Speciale Medica e Metodologia Clinica, Università di Perugia, Perugia, Italy
}

\begin{abstract}
Summary. To assess the effects of ACE-inhibition on insulin action in Type 2 (non-insulin-dependent) diabetes mellitus associated with essential hypertension, 12 patients with Type 2 diabetes (on diet and oral hypoglycaemic agents) and arterial hypertension were examined on two occasions, in a single blind, cross-over study, after two days of treatment with either captopril or a placebo. The study consisted of a euglycaemic-hyperinsulinaemic clamp (two sequential steps of insulin infusion at the rates of $0.25 \mathrm{mU} \cdot \mathrm{kg}^{-1} \cdot \mathrm{min}^{-1}$ and $1 \mathrm{mU} \cdot \mathrm{kg}^{-1} \cdot \mathrm{min}^{-1}, 2 \mathrm{~h}$ each step), combined with an infusion of $3-3 \mathrm{H}$-glucose to measure the rate of hepatic glucose production and that of peripheral glucose utilization. The results show that blood pressure was lower after captopril (sitting, systolic $148 \pm 5 \mathrm{~mm} \mathrm{Hg}$, diastolic $89 \pm 2 \mathrm{~mm} \mathrm{Hg}$ ) compared to placebo $(155 \pm 6$ and $94 \pm 2 \mathrm{mmHg})(p<0.05)$. Captopril treatment resulted in a more suppressed hepatic glucose production ( $2.7 \pm 0.4$ vs $\left.4.94 \pm 0.55 \mu \mathrm{mol} \cdot \mathrm{kg}^{-1} \cdot \mathrm{min}^{-1}\right)$, and a lower plasma non-esterified fatty acid concentration
\end{abstract}

$(0.143 \pm 0.05$ vs $0.200 \pm 0.05 \mathrm{mmol} / \mathrm{l})$ (captopril vs placebo, $p<0.05$ ) at the end of the first step of insulin infusion (estimated portal plasma insulin concentration $305 \pm 28 \mathrm{pmol} / 1)$; and in a greater glucose utilization $(36.5 \pm 5.1$ vs $\left.28 \pm 3.6 \mu \mathrm{mol} \cdot \mathrm{kg}^{-1} \cdot \mathrm{min}^{-1}, p<0.001\right)$ at the end of the second step of insulin infusion (arterial plasma insulin concentration of $604 \pm 33 \mathrm{pmol} / \mathrm{l}$ ). We conclude that captopril improved insulin sensitivity in Type 2 diabetes associated with hypertension at the level of the liver and extrahepatic tissues, primarily muscle and adipose tissue. Thus, in contrast to other antihypertensive drugs such as diuretics and beta-blockers which may have a detrimental effect on insulin action, ACE-inhibitors appear to improve insulin action in Type 2 diabetes and essential hypertension, at least on a short-term basis.

Key words: Insulin resistance, ACE-inhibitors, Type 2 (noninsulin-dependent) diabetes mellitus, essential hypertension, captopril.
It is well established that arterial hypertension is an important risk factor for cardiovascular morbidity and mortality in patients with diabetes mellitus [1], and appropriate treatment of hypertension is strongly recommended in patients with diabetes mellitus [2]. Although non-pharmacological measures may contribute to controlling hypertension [3], anti-hypertensive drugs are almost invariably required for a long-term normalization of high blood pressure.

Theoretically, the presently available anti-hypertensive drugs, i.e. diuretics $[4,5]$, beta-blockers [6], even if "selective" [7], and slow channel calcium entry blockers, at least after short-term administration [8-11], may potentially suppress insulin secretion $[4,6,8-11]$ and/or impair insulin action $[4,5,7]$. Although long-term use of calcium antagonists is not generally considered harmful for glucose homeostasis [12-15], all the anti-hypertensive drugs may ultimately deteriorate either glucose tolerance $[4,6$, $10,11,16,17]$ and/or plasma lipid profile [17-19]. There is some concern that these adverse metabolic effects may in part offset the benefits of long-term treatment of arterial hypertension [20], particularly in diabetic patients who are glucose intolerant by definition, and who frequently exhibit abnormalities of plasma lipid profile.

ACE-inhibitors are becoming popular anti-hypertensive drugs because of their efficacy and low incidence of side effects. Acute [21] and long-term studies [22] have suggested that ACE-inhibitors may increase peripheral insulin sensitivity in Type 2 diabetes [21], and in essential hypertension [22], i.e. in two conditions of insulin resistance $[23,24]$.

At present, with the exception of some uncontrolled reports [25-27], no systematic data are available on the effect of ACE-inhibition on insulin sensitivity in Type 2 diabetes associated with essential hypertension. Clearly, if it were demonstrated that ACE-inhibition improved insulin action in patients with essential hypertension and Type 2 diabetes, where insulin resistance contributes sub- 


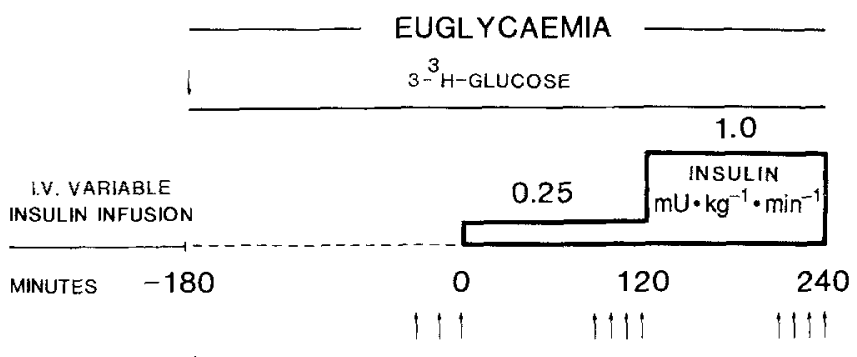

Fig. 1. Design of the euglycaemic-hyperinsulinaemic clamp study

stantially to hyperglycaemia [23], the rationale for using ACE-inhibitors in Type 2 diabetes would become stronger than at present [28].

The present series of studies were undertaken in order to assess whether the ACE-inhibitor captopril, improves the insulin resistance of patients with Type 2 diabetes and essential hypertension; and, if so, to establish the mechanisms.

\section{Subjects and methods}

\section{Patients}

Twelve patients with Type 2 diabetes and mild essential arterial hypertension were studied after obtaining fully informed consent. Their clinical features are given in Table 1. Apart from diabetes and hypertension, the patients were otherwise healthy and free of any detectable diabetes- or hypertension-related complications.

\section{Study design}

After an initial 4-week run-in period during which any anti-hypertensive medication was discontinued, while diet and oral hypoglycaemic agents (in patients 2-6 and 9-12), were continued, baseline blood pressure and fasting plasma glucose were measured. The patients were randomly assigned to a two-day, single blind (patient), cross-over treatment with either captopril ( $50 \mathrm{mg}$ twice daily orally) or placebo after which their insulin sensitivity was studied on the morning of the third day (test day). After a two-week wash-out period during which no anti-hypertensive drugs were given, the patients were again given either captopril or placebo for two days in a crossover fashion, and insulin sensitivity was re-examined on the morning of the third day. Diet and oral hypoglycaemic agents were continued during the two-day treatment with either placebo or captopril and the wash-out periods. However, neither oral hypoglycaemic agents captopril nor placebo were given on the morning of the test day.

\section{Procedures}

On the morning of the test day insulin sensitivity was assessed in all patients by means of the euglycaemic-hyperinsulinaemic clamp technique [29] (Fig. 1). The patients were admitted to the Clinical Research Center of the Istituto di Patologia Medica, Università di Perugia, between 06.30 and 07.00 hours, after overnight fasting $(9-10 \mathrm{~h})$; they were placed on bed rest and maintained in the supine position throughout the experiments. To obtain arterialized-venous blood samples [30], a hand vein was cannulated in a retrograde fashion with a 19-gauge butterfly needle, and the hand maintained at $65^{\circ} \mathrm{C}$ in a thermoregulated plexiglass box. An antecubital vein of the contralateral arm was cannulated with an 18-gauge catheter-needle and kept patent with a $0.9 \% \mathrm{NaCl}$ infusion $(0.5 \mathrm{ml} / \mathrm{min})$. This line was used for infusing insulin, and exogenous glucose, both "cold"

Table 1. Clinical features of the patients. (Mean \pm SEM)

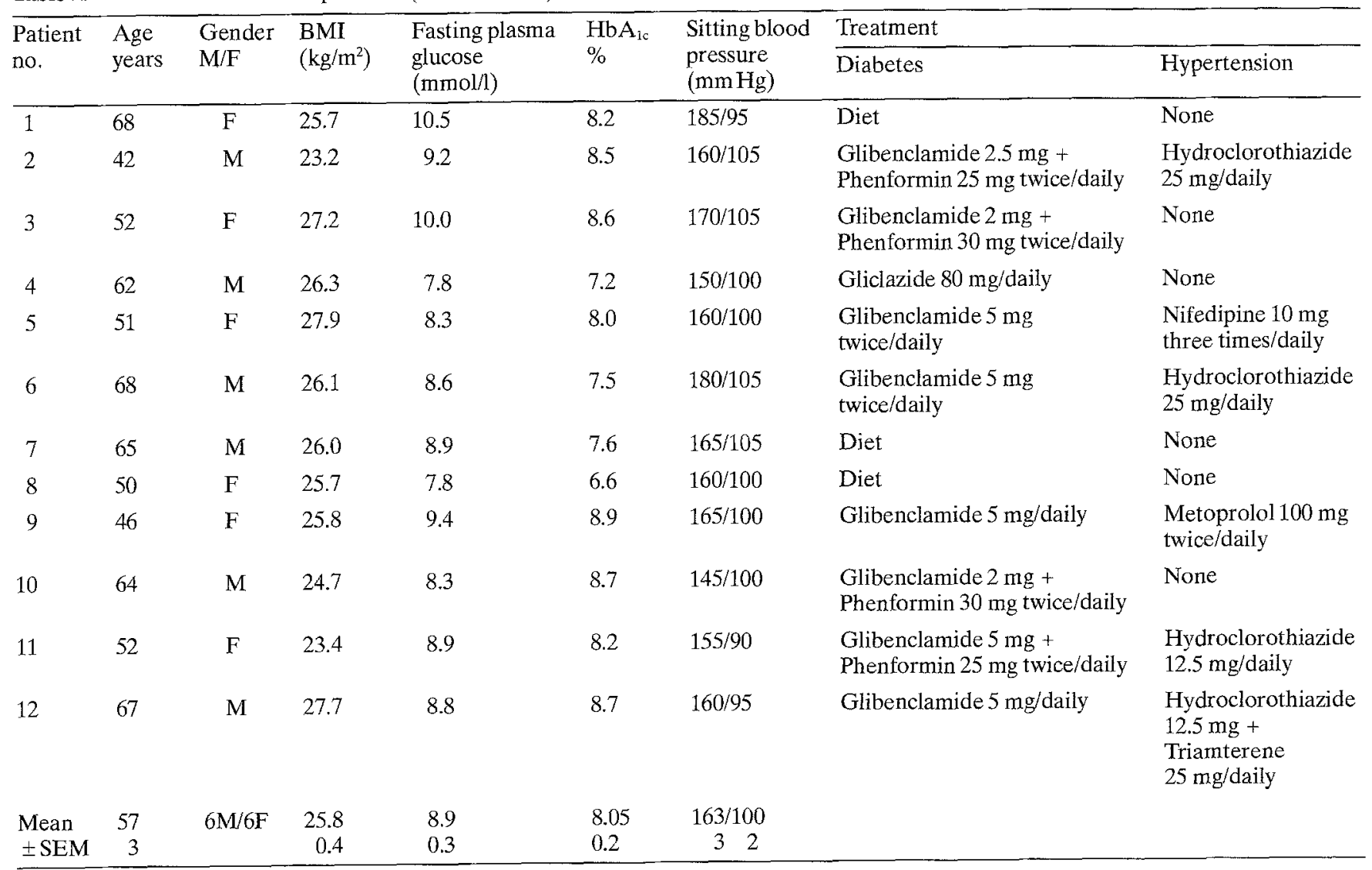


and "hot" (radioactive tracer) (see below). Between 07.00 and 07.30 hours, an infusion of insulin (Actrapid HM U-40, Novo Research Institute, Bagsvaerd, Denmark) diluted to $1 \mathrm{U} / \mathrm{ml}$ in $2 \mathrm{ml}$ of the subject's whole blood and $0.9 \% \mathrm{NaCl}$ to a final volume of $100 \mathrm{ml}$, was given using a syringe pump (Harvard Apparatus, Ealing, South Natick, Mass., USA) in order to gradually decrease the plasma glucose concentration from the patient's hyperglycaemic values to the target of $4.5-5.5 \mathrm{mmol} / 1$, according to a previously described feedback principle [31]. Between 09.00 and 09.30 hours, when plasma glucose concentration decreased between 4.5 and $5.5 \mathrm{mmol} / \mathrm{l}$, the insulin infusion was stopped. A primed $(25 \mu \mathrm{Ci})$-continuous $(0.25 \mu \mathrm{Ci} / \mathrm{min})$ infusion of D-(3- $\left.{ }^{3} \mathrm{H}\right)$-glucose (New England Nuclear, Boston, Mass., USA) was given and maintained throughout the study for isotopic determination of glucose production and utilization. Three hours were allowed for isotopic equilibration, after which baseline blood samples were taken. During this period (from. $-3 \mathrm{~h}$ to time " 0 ") the patients remained spontaneously euglycaemic and no insulin was infused. A euglycaemic-hyperinsulinaemic clamp was started between 12.00 and 12.30 hours (time " 0 "). Insulin was infused during the initial $2 \mathrm{~h}$ at a rate of $0.25 \mathrm{mU} \cdot \mathrm{kg}^{-1} \cdot \mathrm{min}^{-1}$ (first step), followed by two additional hours at a rate of $1 \mathrm{mU} \cdot \mathrm{kg}^{-1}$. $\mathrm{min}^{-1}$ (second step). During both steps of hyperinsulinaemia, cold glucose was infused at a variable rate in order to maintain the plasma glucose concentration at euglycaemic levels, as previously described [32].

\section{Analysis}

Blood samples were collected at 5-10 min intervals and assayed for glucose (Beckman Glucose Analyzer, Beckman Instruments, Fullerton, Calif., USA), glucose specific activity [33], insulin [34], C-peptide [35], and non-esterified fatty acids (NEFA) [36] by previously described methods. Rates of glucose production and utilization were calculated during the last 30 min of each step of the clamp study, by using the non-steady-state equations of De Bodo et al. [37] and were "smoothed" according to the method of Miles et al. [38]. In the second step of the clamp, the calculated rate of hepatic glucose production was negative. Thus, the hepatic glucose production was assumed equal to zero, and the "cold" glucose infusion rate, not the isotopically determined rate of glucose utilization, was considered as the actual rate of peripheral glucose utilization in the second step of the clamp study. Insulin secretory rate was calculated based on changes in plasma C-peptide concentration, with equations derived from a two compartmental model [39]; a distribution space for C-peptide of $80 \mathrm{ml} / \mathrm{kg}$ was used. Portal venous insulin concentrations were calculated as previously described [32].

\section{Statistical analysis}

Data in the text, Table and Figures are given as means $\pm S E M$, and the statistical significance was evaluated using analysis of variance corrected for repeated measures [40]. Regressions were calculated using the least square method [40].

\section{Results}

\section{Blood pressure}

Arterial blood pressure was lower after the two day treatment with captopril than after placebo (sitting, systolic $148 \pm 5$ vs $155 \pm 6 \mathrm{~mm} \mathrm{Hg}$, diastolic $89 \pm 2$ vs $94 \pm 2 \mathrm{~mm} \mathrm{Hg}$, captopril vs placebo, respectively $p<0.05$ ). Heart rate was no different ( $83 \pm 3$ vs $85 \pm 4$ beats per min, after captopril and placebo, respectively $p=\mathrm{NS}$ ).

\section{Baseline fasting plasma glucose and insulin concentrations and feed-back insulin infusion}

On the morning of the study, prior to the intravenous insulin infusion, fasting plasma glucose $(10 \pm 0.55$ vs $9.2 \pm 0.33 \mathrm{mmol} / \mathrm{l})$ and insulin concentrations $(121 \pm 5.9 \mathrm{vs}$ $119 \pm 6.1 \mathrm{pmol} / \mathrm{l})$ after the two-day treatment with either captopril or placebo, respectively, were no different. However, the amount of insulin required to normalize fasting plasma glucose concentration after captopril ( $2.64 \pm 0.28$ Units) was lower compared to that of the placebo study $(3.62 \pm 0.31$ Units $)(p<0.05)$. Also, the duration of the insulin infusion after captopril $(85 \pm 7 \mathrm{~min})$ was lower compared to placebo $(100 \pm 8.4 \mathrm{~min})(p<0.05)$. During the $3 \mathrm{~h}$ equilibration period during which no insulin was infused (from $-3 \mathrm{~h}$ through $0 \mathrm{~h}$ ), mean plasma glucose concentrations in the captopril study $(5.11 \pm 0.22 \mathrm{mmol} / \mathrm{l})$ and in the placebo study $(4.90 \pm 0.19 \mathrm{mmol} / \mathrm{l})$ were no different.

\section{Insulin sensitivity}

Immediately prior to the clamp studies $(0 \mathrm{~h})$, plasma glucose (5.04 \pm 0.14 vs $4.94 \pm 0.18 \mathrm{mmol} / \mathrm{l})$, peripheral plasma insulin $(104 \pm 8.2$ vs $102 \pm 6.6 \mathrm{pmol} / \mathrm{l})$, C-peptide
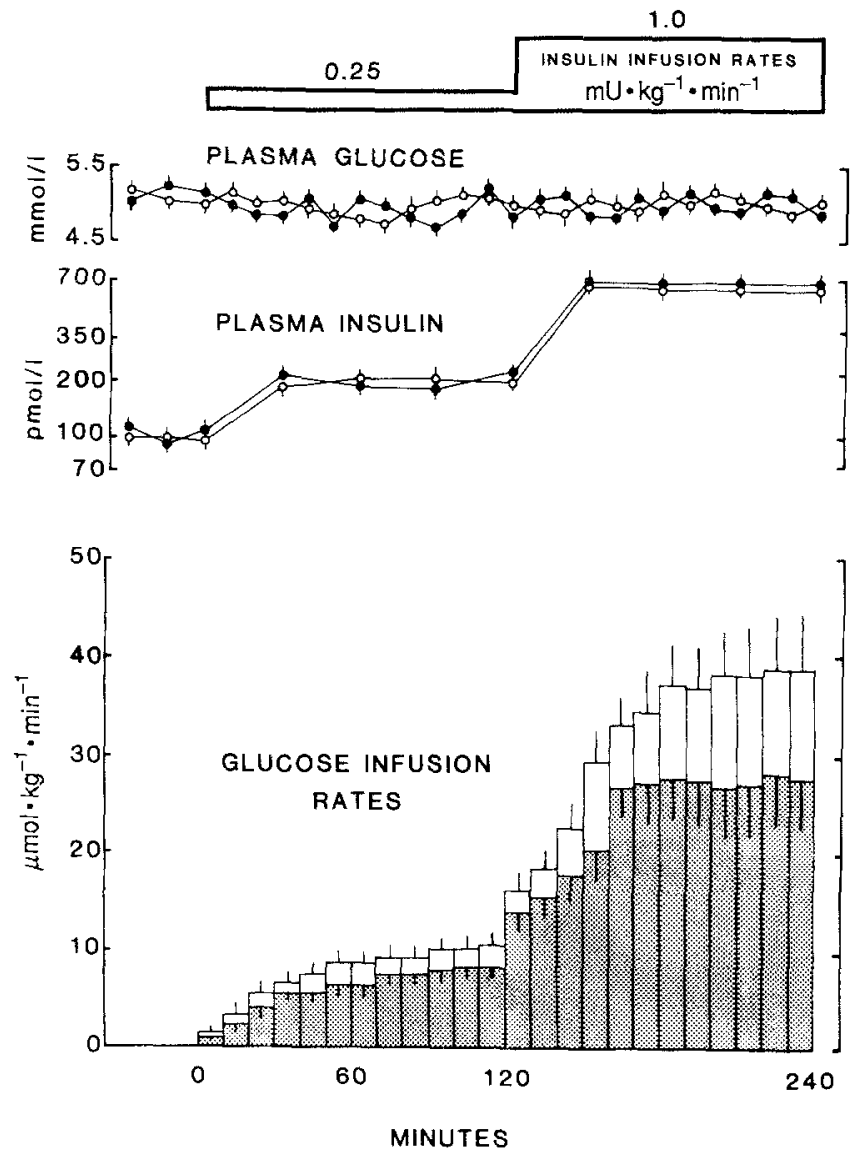

Fig. 2. Plasma glucose and (arterial) insulin concentrations, and rates of infusion of exogenous ("cold") glucose required to maintain euglycaemia during the hyperinsulinaemic clamp in 12 patients with Type 2 diabetes and arterial hypertension after captopril (open circles) and placebo (full circles), respectively. (Mean \pm SEM) 


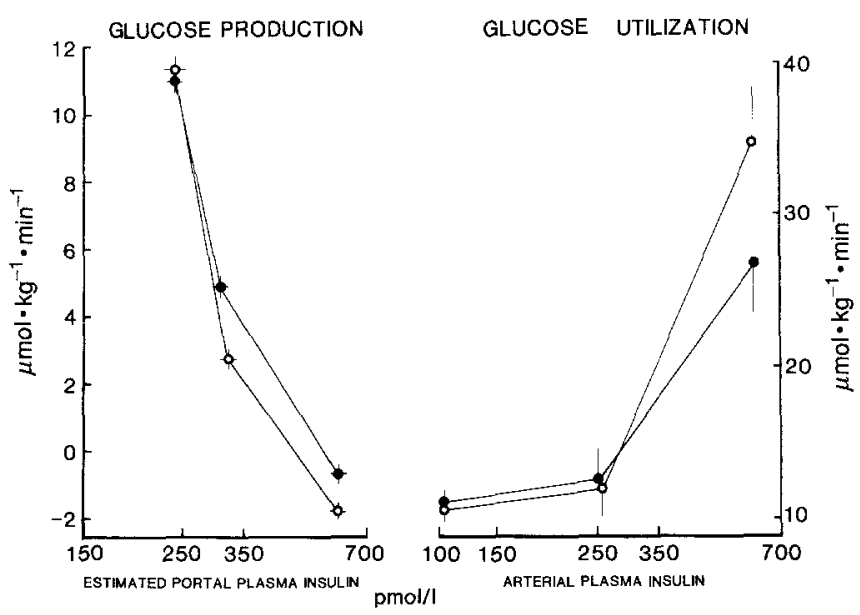

Fig. 3. Rates of glucose production (endogenous, hepatic) and peripheral glucose utilization measured isotopically $\left(3-{ }^{3} \mathrm{H}\right.$-glucose) during the euglycaemic-hyperinsulinaemic clamp in 12 patients with Type 2 diabetes and essential hypertension after captopril (open circles) and placebo (filled circles), respectively. Glucose production is plotted vs estimated portal plasma insulin concentration, glucose utilization vs arterial plasma insulin concentration. (Mean \pm SEM)

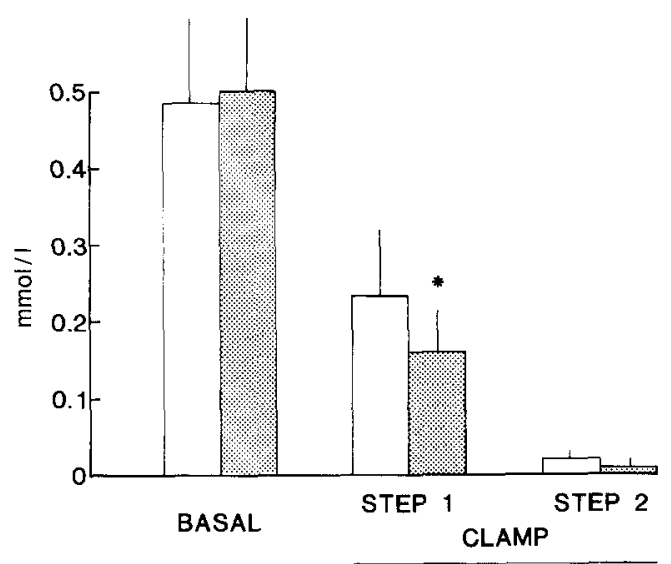

Fig.4. Plasma free fatty acid concentration at baseline and at the end of the two steps of euglycaemic-hyperinsulinaemic clamp in $12 \mathrm{pa}-$ tients with Type 2 diabetes and essential hypertension after captopril (filled bars) and placebo (open bars), respectively. (Mean \pm SEM). $* p<0.05$

( $0.14 \pm 0.01$ vs $0.13 \pm 0.01 \mathrm{pmol} / 1)$, estimated portal plasma insulin $(235 \pm 20$ vs $240 \pm 22 \mathrm{pmol} / \mathrm{l})$, NEFA $(0.54 \pm 0.08$ vs $0.55 \pm 0.08 \mathrm{mmol} / \mathrm{l})$, and potassium ( $4.41 \pm 0.4$ vs $4.31 \pm 0.3 \mathrm{mmol} / \mathrm{l})$ concentrations were no different after captopril and placebo, respectively. Similarly, the rates of glucose production $(11.4 \pm 1.1$ vs $\left.10.8 \pm 1.4 \mu \mathrm{mol} \cdot \mathrm{kg}^{-1} \cdot \mathrm{min}^{-1}\right)$ and glucose utilization $\left(11.3 \pm 1.05 \mathrm{vs} 10.7 \pm 0.99 \mu \mathrm{mol} \cdot \mathrm{kg}^{-1} \cdot \mathrm{min}^{-1}\right)$ at $0 \mathrm{~h}$ were no different after captopril and placebo, respectively (Fig. 2).

During the $4 \mathrm{~h}$ of the hyperinsulinaemic clamp study, euglycaemia was maintained by variable glucose infusion (plasma glucose concentration $5.1 \pm 0.08 \mathrm{mmol} / 1$ after captopril, $5.2 \pm 0.09 \mathrm{mmol} / \mathrm{l}$ after placebo), with a coefficient of variation of $3.4 \pm 0.4 \%$ (captopril) and $3.6 \pm 0.5 \%$ (placebo), respectively, (both $p=\mathrm{NS}$ ). When insulin was infused at the rate of $0.25 \mathrm{mU} \cdot \mathrm{kg}^{-1} \cdot \mathrm{min}^{-1}$, peripheral (arterial) plasma insulin increased to similar steady-state values after captopril $(226 \pm 8.9 \mathrm{pmol} / \mathrm{l})$ and after placebo $(243 \pm 10.8 \mathrm{pmol} / 1)(p=$ NS). Similarly, when insulin was infused at a rate of $1 \mathrm{mU} \cdot \mathrm{kg}^{-1} \cdot \mathrm{min}^{-1}$, the steady state plasma insulin concentration after captopril $(612 \pm 38 \mathrm{pmol} / \mathrm{ml})$ and after placebo $(596 \pm 29 \mathrm{pmol} / \mathrm{l})$ was no different. The plasma C-peptide concentration was suppressed to a comparable extent after captopril and placebo both during the first $(0.09 \pm 0.01 \mathrm{pmol} / 1$ and $0.09 \pm 0.01 \mathrm{pmol} / \mathrm{ml}$ ) and the second step of insulin infusion $(0.07 \pm 0.01$ and $0.08 \pm 0.01 \mathrm{pmol} / \mathrm{l}$ ) (after captopril and placebo, respectively, $p=$ NS) (Fig. 2).

The rate of glucose infusion required to maintain euglycaemia was greater after captopril than after placebo, both at the end of the first step of insulin infusion $\left(90-120 \mathrm{~min}, \quad 9.92 \pm 0.92\right.$ vs $7.65 \pm 0.73 \mu \mathrm{mol} \cdot \mathrm{kg}^{-1}$. $\min ^{-1}$ ), and also at the end of the second step of insulin infusion $(210-240 \mathrm{~min}, 36.5 \pm 5.1$ vs $28 \pm 3.6 \mu \mathrm{mol}$. $\mathrm{kg}^{-1} \cdot \min ^{-1}$ ) (both $p<0.001$ ) (Fig. 2). Hepatic glucose production was more suppressed after captopril as compared to placebo at the end of the first step of insulin infusion $\left(2.7 \pm 0.4\right.$ vs $\left.4.94 \pm 0.55 \mu \mathrm{mol} \cdot \mathrm{kg}^{-1} \cdot \mathrm{min}^{-1}\right)$, when the estimated portal plasma insulin concentration was $305 \pm 27 \mathrm{pmol} / 1$ (captopril) and $310 \pm 29 \mathrm{pmol} / 1$ (placebo) ( $p=\mathrm{NS}$ ), as well as during the second step of insulin infusion where negative figures were obtained $(-1.8 \pm 0.3$ vs $-0.6 \pm 0.04 \mu \mathrm{mol} \cdot \mathrm{kg}^{-1} \cdot \mathrm{min}^{-1}$ ) (both $p<0.003$ ). The rate of peripheral glucose utilization did not increase during the first step of insulin infusion either after captopril or after placebo. However, at the end of the second step of insulin infusion, peripheral glucose utilization increased $30 \%$ more after captopril than after placebo $\left(34.7 \pm 5.44\right.$ vs $\left.26.7 \pm 3.61 \mu \mathrm{mol} \cdot \mathrm{kg}^{-1} \cdot \mathrm{min}^{-1}, p<0.001\right)$ (Fig. 3).

Plasma NEFA was more suppressed at the end of the first step of insulin infusion after captopril compared to placebo $(0.143 \pm 0.05$ vs $0.200 \pm 0.05 \mathrm{mmol} / \mathrm{l}, p<0.05)$, whereas it was maximally suppressed at the end of the second step of insulin infusion both after captopril and placebo (0.04 \pm 0.01 and $0.04 \pm 0.009 \mathrm{mmol} / \mathrm{l}, p=\mathrm{NS}$ ) (Fig.4).

Plasma potassium concentration decreased to similar values at the end of the first step of insulin infusion after captopril $(3.8 \pm 0.4)$ and placebo $(3.81 \pm 0.3 \mathrm{mmol} / \mathrm{l})$, and at the end of the second step of insulin infusion (3.5 \pm 0.5 and $3.6 \pm 0.3 \mathrm{mmol} / \mathrm{l}, p=\mathrm{NS}$ ).

\section{Correlations}

There was no correlation between the decrease in blood pressure and the increase in insulin sensitivity induced by captopril at the liver or peripheral tissue level. Similarly, there was no correlation between the insulin action after placebo and after captopril. No correlation was found between suppression of plasma NEFA or potassium concentration and increased suppression of hepatic glucose production, and stimulated peripheral glucose utilization after captopril. Finally, the improvement in insulin action following captopril in patients previously treated with diuretics did not differ from that of patients previously not treated. 


\section{Discussion}

The present study demonstrates that in patients with Type 2 diabetes and essential hypertension, therapeutic doses of the ACE-inhibitor captopril lower blood pressure and, at the same time, improve insulin action. With the exception of the effect on entry of potassium into cells, ACE-inhibition improved insulin sensitivity at the level of all insulin target organs, namely the liver, where hepatic glucose production was more suppressed, the extra-hepatic tissues (primarily the muscle), where glucose utilization was more stimulated, and the adipose tissue, as indicated by the lower plasma NEFA concentration. In quantitative terms, compared to placebo, ACE-inhibition increased hepatic and extrahepatic (primarily muscle and adipose tissue) insulin sensitivity by $\sim 25 \%$, and $~ 30 \%$, respectively.

A previous study has suggested that acute ACE-inhibition with a single dose of captopril may increase peripheral (muscular) insulin sensitivity within minutes in patients with Type 2 diabetes and normal blood pressure [21]. However, to our knowledge, the present study is the first controlled observation indicating that ACE-inhibition increases insulin sensitivity at the liver and extrahepatic tissue level in patients with Type 2 diabetes and essential hypertension.

Before discussing the results of the present study, it is important to comment on the methodological approach used to examine insulin action in the patients with Type 2 diabetes.

Insulin sensitivity was examined after normalization of plasma glucose by means of an intravenous feedback insulin infusion, which was terminated $3 \mathrm{~h}$ prior to the clamp study to minimize its carry-over effect on the insulin action examined in the subsequent clamp experiments. Interestingly, in the patients with Type 2 diabetes of the present study, the blood glucose concentration did not increase for at least $3 \mathrm{~h}$ after insulin withdrawal. This is in sharp contrast with the exaggerated increase in hepatic glucose production and plasma glucose concentration which develops rapidly in patients with Type 1 diabetes after acute withdrawal of exogenous insulin [41]. Clearly, the difference must be due to the residual pancreatic insulin secretion in patients with Type 2 diabetes in the postabsorptive state [42], which contrasts with the severe portal insulin deficiency occurring in patients with Type 1 diabetes soon after acute insulin withdrawal.

In the present experiments, insulin sensitivity was studied on the "left" part of its dose-response curve for hepatic glucose production $[43,44]$ by infusing insulin at "low" rate $\left(0.25 \mathrm{mU} \cdot \mathrm{kg}^{-1} \cdot \mathrm{min}^{-1}\right)$. In previous studies, it has been difficult to assess hepatic insulin sensitivity in patients with Type 2 diabetes, primarily because of the supraphysiological insulin infusion rates used, which fully suppressed hepatic glucose production, even in cases of severe insulin resistance [23]. On the other hand, since in previous studies plasma glucose concentration was decreased from hyperglycaemic to euglycaemic values immediately prior to the clamp [23], it is likely that the supraphysiological insulin doses which were infused within a few minutes to accomplish this goal, exerted a carry-over effect during the clamp study and overestimated insulin action.

When examined in euglycaemic conditions in the present study, the diabetic patients exhibited a baseline rate of hepatic glucose production of $-11 \mu \mathrm{mol} \cdot \mathrm{kg}^{-1} \cdot \mathrm{min}^{-1}$, which was suppressed by $60 \%$ by an increase in estimated portal plasma insulin concentration of $-310 \mathrm{pmol} / \mathrm{l}$. These data would indicate "normal" hepatic insulin sensitivity $[43,44]$. However, it should be considered that the diabetic patients were hyperinsulinaemic at baseline (plasma insulin concentration $-103 \mathrm{pmol} / 1$ ), and at the end of the first hyperinsulinaemic step ( $-240 \mathrm{pmol} / \mathrm{l})$, as compared to normal, non-diabetic control subjects examined in the post-absorptive state ( $-70 \mathrm{pmol} / \mathrm{l})$, and during an insulin infusion at a rate comparable to that of the first step of the clamp studies in the present experiments ( $144 \mathrm{pmol} / \mathrm{l})$ [44]. In addition, although $3 \mathrm{~h}$ were allowed to elapse between withdrawal of insulin infusion and the beginning of the clamp, it is possible that some carry-over effect of the previously infused insulin was present during the clamp. Taken together, these considerations indicate that the diabetic subjects of the present study were insulinresistant, and, if anything, the experimental approach used to assess insulin action underestimated their insulin resistance.

The results of these studies, i.e. that ACE-inhibition inreases insulin sensitivity at the level of the liver and extrahepatic tissues, are based on the assumption that the isotopically determined rates of glucose production and utilization are a true reflection of the flux rates of glucose during the clamp study. In absolute terms, this assumption is incorrect [45], a fact confirmed in the present studies by the negative values of hepatic glucose production obtained in the second step of the clamp (Fig.3). However, it is likely that the estimate of hepatic glucose output during the first step of the clamp studies of the present experiments is quite accurate, because of the rather low plasma insulin concentration $(250 \mathrm{pmol} / 1)$ and low rate of glucose metabolism $\left({ }^{\circ} 8-10 \mu \mathrm{mol} \cdot \mathrm{kg}^{-1} \cdot \mathrm{min}^{-1}\right)$, namely conditions which minimize the error of the use of Steele's equations [45]. On the other hand, during the second step of the hyperinsulinaemic clamp studies of the present experiments, the rates of infusion of "cold" glucose, not the rates of istopically calculated "hot" glucose utilization, were assumed as the actual rates of peripheral glucose utilization as recently reported [46].

The improvement in the insulin sensitivity after ACEinhibition in the present study occurred primarily during the hyperinsulinaemic clamp, not in the post-absorptive state. This observation, may have several practical implications. Firstly, it is unlikely that fasting plasma glucose concentration will change after treatment with ACE-inhibitors in patients with Type 2 diabetes mellitus, at least on a short-term basis. Secondly, since ACE-inhibition improved both hepatic as well as muscular sensitivity to insulin, and since suppression of hepatic glucose production is a mechanism just as important as the stimulation of glucose uptake for normal glucose tolerance after a meal [47], ACE-inhibition might improve glucose tolerance in response to hyperinsulinaemia following a meal- and/or sulphonylurea administration in patients with Type 2 
diabetes. Such a mechanism might explain the hypoglycaemic episodes reported after acute captopril administration in patients with Type 2 diabetes treated with sulphonylureas [25-27]. Thirdly, it follows that whenever ACE-inhibitors are given to diabetic patients treated with sulphonylureas, blood glucose concentration should be carefully monitored, especially in the late afternoon [48], in order to detect a possible exaggerated anti-hyperglycaemic response to sulphonylureas, and to prevent the onset of clinically overt hypoglycaemia.

The precise mechanism(s) by which ACE-inhibition increased insulin sensitivity in patients with Type 2 diabetes and essential hypertension in the present study, as well as in previous studies $[21,22]$ remains to be established. According to the "haemodynamic" hypothesis, ACE-inhibition would enhance insulin action through arterial vasodilation and increased blood flow [49]. A similar mechanism has been invoked to explain the increased insulin sensitivity after prazosin [50]. Although in a previous study no evidence for an increase in forearm blood flow after captopril was found, it is possible that the noninvasive method used in that study [21] was not sensitive enough to detect minor haemodynamic effects, which might have been important for insulin action. Regarding the "metabolic" hypothesis, the reduced degradation of bradykinin following ACE-inhibition, might exert an insulin-like activity $[51,52]$ which could contribute to the increased glucose utilization observed during hyperinsulinaemia after captopril administration. Regardless of the mechanisms of action, an increase in insulin sensitivity in patients with Type 2 diabetes and essential hypertension has been reported also with other ACE-inhibitors, such as benazepril [53]. On the other hand, in Type 1 diabetes, ACE-inhibition with enalapril does not influence insulin action [54].

Although quantitatively the net effect of ACE-inhibition on insulin action in the present study as well as in previous studies $[21,22,53]$ seems to be quite modest, it may nevertheless be important. In subjects with impaired insulin secretion, even a minor increase in insulin sensitivity might result in less hyperglycaemia [23], which, in turn, might improve insulin secretion and action according to the "gluco-toxicity" hypothesis [55]. In addition, longterm improvement in glucose tolerance after ACE-inhibition might be associated with less hyperinsulinaemia, a well known independent risk factor for atherosclerotic disease [56], and which itself adds to the risk carried by higher blood glucose levels [57], as recently emphasized [58].

In conclusion, therapeutic doses of the ACE-inhibitor captopril control blood pressure, and at the same time improve insulin action at the level of liver and extrahepatic tissues, primarily muscle and adipose tissue in patients with Type 2 diabetes and essential hypertension. This effect primarily occurs when plasma insulin concentration is increased to values approaching those of the post-prandial state, rather than in the post-absorptive state.

Acknowledgements. This work was supported by the Consiglio $\mathrm{Na}-$ zionale delle Ricerche (grants 89.02879.04; and 89.02440.04). The editorial help of Ms. S. Caporaletti and Ms. P. Boyce is gratefully acknowledged.

\section{References}

1. Fuller JH (1985) Epidemiology of hypertension associated with diabetes mellitus. Hypertension 7 [Suppl 2]: 3-7

2. The Working Group on Hypertension in Diabetes (1987) Statement on hypertension in diabetes mellitus. Arch Intern Med 147: 830-842

3. The 1984 Report Of The Joint National Committee on Detection, Evaluation, and treatment of high blood pressure (1984). Arch Intern Med 144: 1405-1507

4. Furman BL (1981) Impairment of glucose tolerance produced by diuretics and other drugs. Phamacol Ther 12: 613-649

5. Dimitriadis G, Leighton B, Parry-Billings $M$, Newsholme EA (1988) Effects of the diuretic furosemide on the sensitivity of glycolysis and glycogen synthesis to insulin in the soleus muscle of the rat. Diabetologia 31: 58-61

6. Östman J (1983) Beta-adrenergic blockade and diabetes mellitus. A review. Acta Med Scand 672 [Suppl]: 69-77

7. Pollare $\mathrm{I}$, Lithell $\mathrm{H}$, Morlin $\mathrm{C}$, Prantare $\mathrm{H}$, Hvarfner A, Ljunghall S (1989) Metabolic effects of diltiazem and atenolol: results from a randomized double-blind study with parallel groups. J Hypertens 7: 551-559

8. Giugliano D, Torella R, Cacciapuoti F, Gentile S, Verza M, Varricchio M (1980) Impairment of insulin secretion in man by nifedipine. Eur J Clin Pharmacol 18: 395-398

9. De Marinis L, Barbarino A (1980) Calcium antagonists and hormone release. I. Effects of verapamil on insulin release in normal subjects and patients with islet-cell tumor. Metabolism 29: 599604

10. Charles S, Ketelslegers J-M, Buysschaert M, Lambert A (1981) Hyperglycaemic effects of nifedipine. Br Med J 283: 19-20

11. Bhatnagar SK, Amin MMA, Al-Yusuf AR (1984) Diabetogenic effects of nifedipine. Br Med J 289: 19

12. Donnelly T, Harrower AD (1980) Effect of nifedipine on glucose tolerance and insulin secretion in diabetic and non-diabetic patients. Curr Med Res Opin 6: 690-693

13. Marre M, Bellet M, Leblanc H, Passa P (1986) Dissociated effects of nicardipine on vascular tone and insulin secretion. J Cardiovase Pharmacol 8: 707-711

14. Collins WCJ, Cullon MJ, Ferley J (1987) Calcium channel blocker drugs and diabetic control. Clin Pharmacol Ther 42:420-423

15. Pasanisi F, Vaccaro O, Ferrara AL, Di Bonito P, Capaldo B, Iovine C, Mancini M (1989) Effect of nicardipine on insulin secretion, glucose and lipid metabolism in hypertensive, non-insulin dependent diabetes. Eur J Clin Pharmacol 36:1-4

16. Belleville I, Vaillant G, Farnier M, Brun JM (1987) La nicardipine peut avoir un effet délétère sur l'équilibre glycémique du diabétique non insulinodépendant. Presse Méd 16:1760-1761

17. Skarfors ET, Lithell HO, Selinus I, Aberg H (1989) Do antihypertensive drugs precipitate diabetes in predisposed man? $\mathrm{Br}$ Med J 298: 1147-1152

18. Schonfeld MR, Goldberger E (1986) Hypercholesterolemia induced by thiazides: a pilot study. Curr Ther Res $6: 180-184$

19. Weidman P, Gerber A, Mordasini R (1983) Effects of antihypertensive therapy on serum lipoproteins. Hypertension 5 [Supi 3]: $120-131$

20. Pollare T, Lithell H, Selinus I, Berne C (1989) Sensitivity to insulin treatment with atenolol and metoprolol: a randomised double blind study of effects on carbohydrate and lipoprotein metabolism in hypertensive patients. Br Med J 298: 1152-1157

21. Jauch KW, Hartl W, Guenther B, Wicklmayr M, Rett K, Dietze $G$ (1987) Captopril enhances insulin responsiveness of forearm muscle tissue in non-insulin-dependent diabetes mellitus. Eur J Clin Invest 17: 448-454

22. Pollare T, Lithell H, Berne C(1989) A comparison of the effects of hydrochlorothiazide and captopril on glucose and lipid metabolism in patients with hypertension. N Engl J Med 321:868-873

23. De Fronzo R (1988) The triumvirate: B-cell, muscle, liver. A collusion responsible for NIDDM. Diabetes 37: 667-687

24. Ferrannini E, Buzzigoli G, Bonadonna R et al. (1987) Insulin resistance in essential hypertension. N Engl J Med 317:350-357 
25. Ferriere M, Lachkar H, Richard JL, Bringer J, Orsetti A, Mirouza J (1985) Captopril and insulin sensitivity. Ann Intern Med 102: 134-135

26. Lederle RM (1985) Captopril and hydrochlorothiazide in the fixed combination multicenter trial. J Cardiovasc Pharmacol 7 [Suppl]: 63-69

27. McMurray J, Fraser DM (1986) Captopril, enalapril, and blood glucose, Lancet I: 1305

28. Sawicki PT, Mühlhauser I, Baba T, Berger M (1990) Do angiotensin converting enzyme inhibitors represent a progress in hypertension care in diabetes mellitus? Diabetologia 33: 121124

29. Andres R, Swerdloff T, Pozefsky T, Coleman D (1966) Manual feedback technique for the control of blood glucose concentration. In: Lt Skeggs $\mathbf{J r}(\mathrm{Ed})$ Automatism in analytical chemistry. New York, Mediad, pp 486-491

30. McGuire E, Helderman J, Tobin R, Andres R, Berman M (1976) Effects of arterial versus venous sampling on analysis of glucose kinetics in man. J Appl Physiol 41: 565-573

31. De Feo P, Perriello G, Ventura MM et al . (1986) Studies on overnight insulin requirements and metabolic clearance rate of insulin in normal and diabetic man: relevance to the pathogenesis of the dawn phenomenon. Diabetologia 29:475-480

32. De Feo P, Perriello G, De Cosmo S et al. (1986) Comparison of glucose counterregulation during short-term and prolonged hy poglycemia in normal humans. Diabetes $35: 563-569$

33. Rizza A, Cryer PE, Gerich JE (1979) Role of glucagon, catecholamines, and growth hormone in human glucose counterregulation: effects of somatostatin and combined a- and b-adrenergic blockade on plasma glucose recovery and glucose fhux rates after insulin-induced hypoglycemia. J Clin Invest 64: 62-71

34. Herbert V, Lav KS, Gottlieb G, Bleicher SJ (1965) Coated charcoal immunoassay of insulin. J Endocrinol Metab 25: 1375-1379

35. Faber O, Binder C, Markussen J, Heding L, Naithand V, Kuzuya H, Blix P, Horwitz D, Rubenstein A (1978) Characterization of seven C-peptide antisera. Diabetes 27 [Suppl 1]: 170-177

36. NEFA C. Enzymatic colorimetric method for the quantitative determination of FFA in serum. Wako Chemicals, Neuss

37. De Bodo R, Steele R, Altzuler N, Dunn A, Bishop J (1963) On the hormonal regulation of carbohydrate metabolism: studies with $\mathrm{C}^{14}$ glucose. Recent Prog Horm Res 19: 445-448

38. Miles J, Haymond M, Gerich JE (1982) Effects of free fatty acids, insulin glucagon and adrenalin on ketone body production in humans. In: Metabolic acidosis, Ciba Foundation Symposium 87, Pitman, London, pp 192-213

39. Eaton R, Allen R, Shade D, Erickson K, Standefer J (1980) Prehepatic insulin production in man: kinetic analysis using peripheral connecting peptide behaviour. J Clin Endocrin Metab 51: 520-528

40. Zar J (1984) Biostatistical analysis. Prentice Hall, Englewood Cliffs New Yersey

41. Miles JM, Rizza RA, Haymond MW, Gerich JE (1980) Effects of acute insulin deficiency on glucose and ketone body turnover in man. Diabetes 29: 926-930

42. Bolli GB, Tsalikian E, Haymond MW, Cryer PE, Gerich JE (1984) Defective glucose counterregulation after subcutaneous insulin in non-insulin dependent diabetes mellitus: paradoxical suppression of glucose utilization and lack of compensatory increase in glucose production, roles of insulin resistance, abnormal neuroendocrine responses, and islet paracrine interactions. J Clin Invest 73: 1532-1541

43. Rizza M, Mandarino L, Gerich J (1981) Dose-response characteristics for effects of insulin on production and utilization of glucose in man. Am J Physiol 240: E630-E639
44. Nurjhan N, Campbell PJ, Kennedy FP, Miles JM, Gerich JE (1986) Insulin dose-response characteristics for suppression of glycerol release and conversion to glucose in humans. Diabetes 35: 1326-1331

45. Cobelli C, Mari A, Ferrannini E (1987) The non-steady state problem: error analysis of Steele's model and new development for glucose kinetics. Am J Physiol 252: E679-E689

46. Perriello G, De Feo P, Torlone E, Fanelli C, Santeusanio F, Brunetti P, Bolli GB (1990) Nocturnal spikes of growth hormone secretion cause the dawn phenomenon in Type 1 (insulindependent) diabetes mellitus by decreasing hepatic (and extrahepatic) sensitivity to insulin in the absence of insulin waning. Diabetologia 33:52-59

47. Gerich JE (1988) Role of insulin resistance in the pathogenesis of NIDDM. Balliere's Clin Endocrinol Metab 2: 307-326

48. Trovati M, Mularoni E, Massucco P, Burzacca S, Malvaso MR, Anfossi G, Emanuelli G (1989) Study on the occurrence of blood glucose concentrations under the target of $4.4 \mathrm{mmol} / 1$ in a cohort of 463 Type 2 diabetic patients. Diabetologia 32: 549A

49. Douglas WW (1985) Polypeptides-angiotensin, plasma kinins and others. In: Goodman LS and Gilman JAG (eds) The pharmacological basis of therapeutics. MacMillan, New York, pp 639-659

50. Pollare T, Lithell H, Selinus I, Berne C (1988) Application of prazosin is associated with an increase of insulin sensitivity in obese patients with hypertension. Diabetologia 31:415-420

51. Dietze GJ (1982) Modulation of the action of insulin in relation to the energy state in skeletal muscle. Possible involvement of kinins and prostaglandins. Mol Cell Endocrinol 25: 127-149

52. Jauch K-W, Guenther B, Hartl W, Rett K, Wicklmayr M, Dietze G (1986) Improvement of impaired postoperative insulin action by bradykinin. Biol Chem Hoppe-Seyler 367: 207-210

53. De Feo P, Bolli GB, Motolese M, Brunetti P (1989) Benazepril improves glycaemic control in patients with Type 2 diabetes and essential hypertension. The International Symposium on ACEinhibition, London, February 14-17, Abs F078

54. Seefeldt T, Orskov L, Rasmussen O, Pedersen MM, Moller N, Christiansen JS, Schmitz O (1990) Lack of effects of angiotensinconverting enzyme inhibitors on glucose metabolism in insulindependent diabetes mellitus. Diabetic Med 7:700-704

55. Unger R, Grundy S (1985) Hyperglycemia as an inducer as well as a consequence of impaired islet function and insulin resistance: implication for the management of diabetes. Diabetologia 28: 119-121

56. Stout RW (1985) Overview of the association between insulin and atherosclerosis. Metabolism 34 [Suppl 1]: 7-12

57. Wingard DL, Barrett-Connor E (1987) Family history of diabetes and cardiovascular disease risk factors and mortality among euglycemic, borderline hyperglycemic and diabetic adults. Am J Epidemiol 125: 948-958

58. Ferrannini E, De Fronzo R (1989) The association of hypertension, diabetes, and obesity: a review. J Nephrol 1: 3-15

Received: 7 May 1990

and in revised form: 18 October 1990

Prof. G. B. Bolli

Istituto Patologia Medica

dell'Università di Perugia

Via E. Dal Pozzo

I-06100 Perugia

Italy 